\title{
CRITERIA IN ANAEROBIC FERMENTATION TESTS
}

\author{
I VAN C. H ALL \\ From the Department of Batteriology and Experimental Pathology, University of California \\ Berkoley, Calif.
}

The most fundamental premise in the differentiation and identification of micro-organisms through determination of their metabolic functions rests in the unquestioned purity of the culture under study; a mixture of species gives, as a rule, a result that represents the sum of the properties possessed by the individual strains represented. On account of the confusions growing out of fermentation and other cultural tests conducted with impure cultures, little headway was made previous to the war in the taxonomy of the obligate anaerobes.

Impurity of culture need no longer be considered an insurmountable difficulty in the taxonomy of the anaerobes, for, while an almost meticulous anxiety must be exercised in order to avoid contaminations, both deep and surface culture methods exist which suffice for isolation if repeatedly and conscientiously applied. Except in rare instances the purification problem is a solved problem.'

Assuming the problem of purity to be settled, one is justified, in view of the great utility of the fermentation reactions in aerobic bacteriology, in inquiring to what extent they may be applied in the differentiation and identification of obligate anaerobes. There has been until recently a widespread impression that the usual (i. e., aerobic) criteria of fermentation, namely, acid and gas production, encounter serious limitations in the interpretation of fermentation tests of anaerobes. It is the purpose of this paper to formulate these limitations in the belief that the taxonomic utility of the fermentation reactions is no less for the obligate anaerobes than for the aerobes, providing certain conditions are met. The constricted fermentation tube with mechanical seal ${ }^{2}$ has been of considerable aid in this study.

What is THE TRUE CRITERION CF ANAEROBIC FERMENTATION?

The writer's attention was first drawn to the difficulties in the proper interpretation of anaerobic fermentation tests in 1916. Certain cultures in our possession at that time could be divided into two metabolic

Received for publication June 6, 1921 .

1 Hall: Jour. Infect. Dis., 1920, 27, p. 576

2 Hall: Ibid, 1921, 29, p. 314. 
groups; in one there was a marked putrefactive tendency as shown in the blackening and digestion of a brain medium; in the other there was no such tendency. This distinction was equally marked in the action of these organisms on milk in the constricted tube.

In the putrefactive group growth in milk was at first slow, often not evident at all until after 36-48 hours, when a soft solid curd with little or no gas was formed. After 72 hours liquefaction had usually begun, accompanied by some gas production as the coagulated casein digested. Such cultures were always foul in odor.

In the nonputrefactive group several types of change were noted, such as rapid coagulation of casein with vigorous, "stormy" gas production, slow coagulation with moderate gas formation, gas formation without coagulation or no visible change. In such cultures there was never liquefaction or digestion of the casein, and the odor was not foul.

It was surprising to find that the "titratable acidity," using phenolphthalein as an indicator, was frequently higher in milk cultures of the putrefactive type than in milk cultures of the nonputrefactive group. But with our growing appreciation of the importance and significance of the $\mathrm{H}^{+}$ion concentration, and our belief that lactose could not be fermented in milk without inhibiting putrefaction, it was not surprising to find that the reaction of the putrefactive cultures had actually changed slightly in the direction of alkalinity without, however, passing the changing point of phenolphthalein. These results have been twice repeated recently with a representative group of carefully purified and identified cultures, as shown in table 1 .

Fresh pasteurized cow's milk was sterilized in the new constricted fermentation tube with marble seal ${ }^{2}$ by the intermittent method. Daily observations on the macroscopic changes were made for one week. Gas production was estimated with Frost's gasometer. Aerobic contamination was excluded by subculturing on the surface of plain agar plates, all of which remained barren on incubation.

The direction of reaction change was determined by withdrawing three $0.5 \mathrm{cc}$ portions of culture fluid from the closed branch of the tube after removing the rubber stopper thereof, placing them in the depressions of a white porcelain test plate and adding to one, 2 drops of $0.04 \%$ aqueous solution of brom-thymol-blue, to another, 2 drops of $0.02 \%$ alcoholic solution of methyl-red, and to the third, 2 drops of $0.04 \%$ aqueous solution of brom-phenol-blue. 
The titer was determined with two indicators, namely, phenolphthalein and brom-thymol-blue.

Of the first, $1 \mathrm{cc}$ of a $0.5 \%$ solution in $50 \%$ alcohol was added to $5 \mathrm{cc}$ of culture fluid diluted with $25 \mathrm{cc}$ of neutral distilled water. This mixture was brought barely to boiling and titrated while hot to the first permanent tint of pink with $\mathrm{N} / 20 \mathrm{NaOH}$.

Of the second indicator, $1 \mathrm{cc}$ of $0.04 \%$ aqueous solution was added to $5 \mathrm{cc}$ of culture fluid likewise diluted with $25 \mathrm{cc}$ of neutral distilled water but titrated cold against $\mathrm{N} / 20 \mathrm{NaOH}$ to the color of $30 \mathrm{c} \mathrm{c}$ of a standard buffer solution $\left(\mathrm{P}_{\mathrm{H}}=7.0\right)$ with an equal amount of dye in a white evaporating dish.

TABLE 1

Action of Certain Obligate Anaeroges in Milk in the Constricted fermentation Túb

\begin{tabular}{|c|c|c|c|c|c|c|c|}
\hline $\begin{array}{l}\text { Cul- } \\
\text { ture } \\
\text { No. }\end{array}$ & $\begin{array}{l}\text { Culture } \\
\text { Name }\end{array}$ & $\begin{array}{c}\text { Visible } \\
\text { Change }\end{array}$ & $\begin{array}{c}\text { Total } \\
\text { Gas, } \\
\%\end{array}$ & $\begin{array}{c}\text { Titer } \\
\text { to } \\
\text { Phenol- } \\
\text { phthal- } \\
\text { ein }\end{array}$ & $\begin{array}{l}\text { T'iter } \\
\text { to } \\
\text { Brom- } \\
\text { thymol- } \\
\text { blue }\end{array}$ & Terminal Reactions & $\begin{array}{l}\text { Reac- } \\
\text { tion } \\
\text { Change }\end{array}$ \\
\hline $\begin{array}{l}\text { Con- } \\
\text { trol }\end{array}$ & Uninoculated & None & 0 & +2.8 & +1.8 & $\begin{array}{l}\text { Alkaline to methyl-red; } \\
\text { slightly acid to brom- }\end{array}$ & None \\
\hline 1 & B. tetani & None & 0 & +2.9 & +1.6 & $\begin{array}{l}\text { Alkaline to methyl-red; } \\
\text { acid to brom-thymol- } \\
\text { blue }\end{array}$ & Sl. alk. \\
\hline 2 & B. welchij & $\begin{array}{l}\text { Stormy fer- } \\
\text { mentation }\end{array}$ & 100 & +8.4 & $\ldots .$. & $\begin{array}{l}\text { Alkaline to brom-phenol- } \\
\text { bltue; acid to methyl-red }\end{array}$ & Acid \\
\hline 4 & Vibrion septique & $\begin{array}{l}\text { Slow coagu- } \\
\text { lation only }\end{array}$ & 0 & +3.7 & 2.1 & $\begin{array}{c}\text { Alkaline to brom-phenol- } \\
\text { blue; acid (?) to } \\
\text { methyl-red }\end{array}$ & Acid \\
\hline $8 A$ & B. botulinus & $\begin{array}{l}\text { Putrefac- } \\
\text { tive }\end{array}$ & 8 & +10.8 & 2.3 & $\begin{array}{l}\text { Alkaline to methyl-red; } \\
\text { nearly neutral to brom- } \\
\text { thymol-blue }\end{array}$ & Alk. \\
\hline 10 & B. sporogenes & $\begin{array}{l}\text { Putrefac- } \\
\text { tive }\end{array}$ & 5 & +8.0 & 3.5 & $\begin{array}{l}\text { Alkaline to methyl-red; } \\
\text { nearly neutral to brom- } \\
\text { thymol-blue }\end{array}$ & Alk. \\
\hline 50 & B. bifermentans & $\begin{array}{l}\text { Putrefac- } \\
\text { tive }\end{array}$ & 8 & +8.7 & 2.5 & $\begin{array}{l}\text { Alkaline to methyl-red; } \\
\text { nearly neitral to broul } \\
\text { thymol-blue }\end{array}$ & Alk. \\
\hline
\end{tabular}

On account of the opacity of the undigested casein in certain cultures and the marked color in those cultures of which the casein was digested, it was impossible to apply colorimetric methods to the exact determination of the terminal $\mathrm{H}^{+}$ion concentrations ; but by comparing the color in the test plate of equivalent amounts of culture fluid containing equal quantities of brom-thymol-blue, the direction of the reaction change could be determined as noted.

The reaction change of the putrefactive cultures, B. botulinus, B. sporogenes, and B. bifermentans was distinctly in the direction of alkalinity as contrasted with the uninoculated control, that of the non-fermentative, slightly putrefactive B. tetani slightly so. It is 
notable that in none of these was the reaction distinctly alkaline to the true neutral point, i. e., $\mathrm{P}_{\mathrm{H}}=7$. Yet while the markedly putrefactive cultures $(8 \mathrm{~A}, 10$ and 50$)$ indicated a higher $\mathrm{OH}$-concentration than $\mathrm{B}$. tetani, they also required more alkali to bring them to the true neutral point, as shown in the titration values. The latter must therefore be interpreted as indicative of a great increase in buffer capacity through proteolysis. Foster and Randa11 ${ }^{3}$ have confirmed Robertson's explanation of this phenomenon which considers that the $-\mathrm{COHN}$ - groups of the protein molecule become available for neutralization of acids and bases during hydrolysis.

B. welchii and Vibrion septique, especially the former, gave distinct changes in the direction of acidity.

Of the nonputrefactive organisms, only $B$. welchii produced a titratable acidity comparable with those of the putrefactive organisms. The unreliability of using titratable acidity as a criterion of the direction of reaction changes is striking displayed. Even the use of bromthymol-blue may lead one astray in the case of milk because, while certain putrefactive organisms may change the reaction in the direction of alkalinity, this change may not even reach the true neutral point. The only proper point of reference therefore is the reaction of the uninoculated control.

Gas was produced in slight amount by all the putrefactive cultures and abundantly by $B$. welchii.

The cultures mentioned in table 1 must be considered not only from the standpoint of their obvious action on casein, but also from the standpoint of their known action on carbohydrates. Three groups are represented. B. tetani is to be regarded as not directly fermenting any carbohydrate. ${ }^{4}$ B. Welchii, ${ }^{5}$ Vibrion septique, and B. Chauvoei ${ }^{B}$ ferment both monosaccharides and the disaccharide lactose, while the putrefactive anaerobes, B. botulinus, B. sporogenes and B. bifermentans ferment only monosaccharides. ${ }^{7}$

No one will question the fermentation of milk sugar by B. welchii, Vibrion septique and B. Chauvoei. But Wolfe and Harris ${ }^{8}$ have shown that the lactose of milk is consumed by certain putrefactive

${ }^{3}$ Foster: Jour. Bacteriol., 1921, 6, p. 143.

4 Adamson: Jour. Path. \& Bacteriol., 1920, 6, p. 143

5 Simonds: Monograph No. 5, Rockefeller Inst. for Med. Research, 1915. Jablons: Jour. Lab. and Clin. Med., 1920, 5, p. 374. Esty: Jour. Bact., 1920, 5, p. 375.

- Robertson: Brit. Med. Jour., 1918, 1, p. 583,

7 Weinberg and Séquin: La Gangrène gazeuse, 1918.

s Jour. Path. \& Bacteriol,, 1917, 21, p. 386. 
anaerobes, notably B. sporogenes, and this view is further supported by the failure of our putrefactive organisms to carry the alkalinity past the neutral point. How can this apparent fermentation of lactose in milk with acid and gas production be harmonized with the fact that in deep litmus-lactose agar one produces some gas, it is true, but only an alkaline reaction with these putrefactive anaerobes? The following explanation is offered. It may be presumed that the initial curd formation is due to acid formed from the slight trace of glucose present in milk. When this is exhausted proteolysis begins and sufficient ammonia is generated to begin the hydrolysis of lactose to glucose. From that time forward in the cultures fermentation and proteolysis go on side by side in the culture maintaining for days a balance that finally results in the almost complete destruction of both the high protein content and the high lactose content of the milk.

It was at this point that a critical survey of the problem of anaerobic fermentation was begun. For purposes of discussion gas and acid as criteria of fermentation are considered separately although in the experiments the possible correlation of these phenomena was kept constantly in mind.

\section{GAS AS A CRITERION OF ANAEROBIC FERMENTATION}

With aerobic bacteria gas formation is universally regarded as one evidence of fermentation.

The use of gas production as a criterion in fermentation tests of obligate anaerobes was suggested by Theobald Smith $^{\circ}$ in 1890 . Smith proposed the use of mercury as an air seal in the fermentation tube, but a recent letter from Professor Smith states that he never tried it, and the writer in collaboration with Miss Jeanette Gay of the University of California has shown that mercury cannot be used as a seal on account of its inhibition of growth. Smith ${ }^{\text {th. }}$ " later overcame the initial failure of anaerobes to grow in the fermentation tube by the narrowing of the neck of the tube and by the use of sterite tissues in the medium, and with Brown and Walker ${ }^{12}$ studied the gas production of several anaerobic cuitures. The production of some gas in mediums presumably freed from sugar by Bact. coli to which tissues were subsequently added, was recognized as an obstacle in the interpretation of the tests. The omission of tisstes was therefore advised. Randall and Hall ${ }^{13}$ have recently shown the inadequacy of Bact. coli in the preparation of sugar-free mediums for fermentation tests of anaerobes.

- Centralbl. f. Bakteriol., 1890,7 , p. 502. Co., 1893 .

to The Fermentation Tube, Wilder Quarter Century Book, Ithaca, N. Y., Comstock Pub.

\footnotetext{
11 Centr. f. Bakt., 1895, 18, p. 1.

19 Jour. Med. Research, 1905, 14, p. 193.

13 J. Infect. Dis., 1921, 29, p. 314.
} 
Meyer, ${ }^{14}$ Robertson, ${ }^{15}$ and Esty ${ }^{5}$ and others have at least tacitly regarded gas along with acid as a criterion of sugar splitting in the fermentation tube. Epstein ${ }^{18}$ invented a special form of apparatus for the study of anaerobic gas, and Beattie ${ }^{17}$ used the gas formation under petrolatum in minute tubes as in economical method of determining the fermentation reactions of anaerobes.

Henry ${ }^{18}$ clearly recognized the difficulties in the problem. Studying the reactions in a neutral casein digest tubed in a Durham fermentation tube with an oblique vial similar to the writer's modification, ${ }^{10}$ he concluded that while both gas and acid may serve as criteria of anaerobic fermentation, gas is of doubtful value unless produced abundantly during the first 24 hours of incubation.

Some writers have proposed to regard carbon dioxide as the proper criterion of fermentation. Smith, Brown and Walker ${ }^{22}$ particularly emphasized the $\frac{\mathrm{CO}_{2}}{\text { Total gas }}$ ratio. However, Keyes, ${ }^{20}$ and Keyes and Gillespie ${ }^{21}$ showed that the quantitative significance of gas ratios obtained from the ordinary fermentation tube is doubtful. Notwithstanding, Todd ${ }^{22}$ and Simonds ${ }^{5}$ have since gone to considerable pains to record such values for certain anaerobes. Apparatus and methods 'to obviate the well-known sources of error in the gas ratios so determined have been most highly developed by Wolf, Harris and Telfer. ${ }^{23}$

It occurred to the writer that the marble seal in the constricted fermentation tube might suppress outward diffusion of carbon dioxide sufficiently to yield gas ratios comparable in accuracy to those obtained by more elaborate methods. Mr. Noah Fox collaborated at the University of Chicago in an attempt to correlate the ratios as determined for glucose broth in the constricted tube with marble seal and in sealed flasks.

In this work, meat infusion $1 \%$ glucose broth, $\mathrm{P}_{\mathrm{H}}=7$, was filled into the tubes and also into small Erlenmeyer flasks of about $200 \mathrm{c}$ c capacity. The flasks were filled about half full, and the flasks were stoppered with rubber stoppers perforated to receive glass stopcocks. With some caution these were sterilized and inoculated in duplicate while yet warm with cultures under study. They were immediately evacuated with an oil vacuum pump and incubated at $37 \mathrm{C}$. Parallel cultures were made in constricted fermentation tubes.

Following various periods of incubation the flasks were connected with a Hempel gas apparatus, and since no mercury pump was avail-

14 Jour. of Infect. Dis., 1915, 17, p. 458.

15 Jour. Path. \& Bacteriol, 1916, 20, p. 327.

10 Centralb1. f. Bakteriol., 1898, 24, p. 266.

17 Brit. Med. Jour., 1916, 1, p. 756.

18 Jour. Path. \& Bacteriol., 1917, 21, p. 344.

10 Hall: Amer. Jour. Public Health, 1914, 4, p. 1173.

20 Jour. Med. Research, 1909, 21, p. 69.

21 Jour. Biol. Chem., 1912-13, 13, pp. 291 and 305.

22 Jour. Infect. Dis., 1917,5, p. 20.

23 Jour. Path. \& Bacteriol., 1916, 21, p. 386; 1918, 22, pp. 1 and 115; 1919, 23, p. 30; Biochem. Jour., 1917, 21, pp. 197 and 213. 
able, the dissolved gas contained in the liquid, after the initial release of pressure, was driven off by boiling gently. This procedure was recognized as a possible source of error, owing to an increase in the total gas volume due to water vapor. At any rate, the carbon dioxide ratio was so determined and compared with that in the fermentation tube.

The gas produced in the constricted fermentation tube was first measured with Frost's gasometer and recorded in percentage of the total length of the closed arm occupied by the gas. Immediately following, the open branch was completely filled with $10 \% \mathrm{NaOH}$ and stoppered with a rubber stopper in such a way as not to inclose any air. The gas collected in the closed arm was then rocked into contact, shaken

TABLE 2

A Comparison of Carbon Dioxide Ratios Obtained from Sealed Flasks and from the Constricten Fermentation Tube with Marble Seal

\begin{tabular}{|c|c|c|c|c|c|c|}
\hline \multirow[t]{2}{*}{ Cuiture } & \multirow{2}{*}{$\begin{array}{l}\text { Experi- } \\
\text { ment } \\
\text { Number }\end{array}$} & \multirow{2}{*}{$\begin{array}{l}\text { Period } \\
\text { of Incn- } \\
\text { bation, } \\
\text { Hours }\end{array}$} & \multicolumn{2}{|c|}{ Flask* } & \multicolumn{2}{|c|}{$\begin{array}{l}\text { Constricted Fermen- } \\
\text { tation Tube* }\end{array}$} \\
\hline & & & $A$ & $\mathrm{~B}$ & $A$ & $\mathrm{~B}$ \\
\hline B. welchii 2 & $\begin{array}{l}1 \\
2 \\
3 \\
4\end{array}$ & $\begin{array}{l}48 \\
64 \\
48 \\
48\end{array}$ & $\begin{array}{l}32.8 \\
29.9 \\
30.9 \\
31.5\end{array}$ & $\begin{array}{l}33.0 \\
29.9 \\
29.6 \\
32.7\end{array}$ & $\begin{array}{l}35 \\
30 \\
39 \\
36\end{array}$ & $\begin{array}{l}38 \\
36 \\
36 \\
34\end{array}$ \\
\hline B. welchii 20 & $\begin{array}{l}5 \\
6 \\
7\end{array}$ & $\begin{array}{l}64 \\
48 \\
48\end{array}$ & $\begin{array}{l}20.0 \\
20.0 \\
29.5\end{array}$ & $\begin{array}{l}27.0 \\
28.8 \\
30.6\end{array}$ & $\begin{array}{l}34 \\
33 \\
29\end{array}$ & $\begin{array}{l}33 \\
35 \\
10\end{array}$ \\
\hline B. welchil 36 & $\begin{array}{r}8 \\
9 \\
10\end{array}$ & $\begin{array}{l}64 \\
48 \\
48\end{array}$ & $\begin{array}{r}16.9 \\
8.8 \\
11.0\end{array}$ & $\begin{array}{r}18.2 \\
9.9 \\
9.0\end{array}$ & $\begin{array}{r}19 \\
6 \\
16\end{array}$ & $\begin{array}{r}20 \\
5 \\
10\end{array}$ \\
\hline Bact. coli & $\begin{array}{l}11 \\
12\end{array}$ & $\begin{array}{l}48 \\
48\end{array}$ & $\begin{array}{l}53.0 \\
49.0\end{array}$ & $\begin{array}{l}52.0 \\
51.0\end{array}$ & $\begin{array}{l}36 \\
39\end{array}$ & $\frac{21}{37}$ \\
\hline
\end{tabular}

* The figures indicate percentage of carbon dioxide in the tolal amount of gas produced.

thoroughly, and rocked back into the closed arm; the large rubber stopper was then removed, the residual gas was measured and the difference estimated as carbon dioxide in percentage of the total gas production. The unselected results of these experiments are recorded in table 2 for 3 carefully purified and identified strains of $B$. welchii and a single strain of Bact. coli.

Comparing the duplicates in each experiment as summarized in the foregoing, relatively few discrepancies are seen although certain exceptions occur as in exper. 7,10 and 11. These are inexplicable except on an assumption of possible differences in rate of growth, such as might be attributed to variations in size of inocula or possibly to unknown factors. Larger discrepancies occurred in the tubes than in the flasks. 
It is curious that, with the exception of exper. 7 and 9, the carbon dioxide ratios for $\mathrm{B}$. welchii averaged higher in the tubes than in the flasks. This difference may have been attributable to an error introduced in the water vapor as suggested, but that could scarcely be an adequate explanation of the result for Bact. coli where the opposite result was obtained in the two experiments tried.

Of the 3 strains of $\mathrm{B}$. welchii, culture 36 always gave a lower carbon dioxide ratio than the other 2 . It so happens that this culture is considerably more pathogenic for guinea-pigs also, although cross protection experiments performed with these strains showed that the 3 are homologous in antigenic action.

The differences in consecutive experiments merely indicate the reticence which should be exercised in attaching any absolute importance to the values recorded. They illustrate some of the possible fallacies in gas ratio records as determined either by the simple means of fermentation tubes or the more elaborate methods of gas analysis.

This conclusion is supported by inspection of table 3 which summarizes the data obtained in an experiment to determine whether among the species available for the test certain ones present especial difficulties in the interpretation of the criteria of fermentation on a medium presumably sugar-free and on the same medium plus $1 \%$ glucose. The medium used was $2 \%$ peptone meat infusion broth which had been fermented out with B. welchii for 6 days. The writer has engaged with $\mathrm{Mr}$. S. B. Randall in a study of the comparative value of $B$. welchii and Bact. coli for this purpose, which indicates certain points of superiority in B. welchii. ${ }^{13}$ In preparing this medium $\mathrm{H}^{+}$ ion concentration and titratable acidity curves were carefully followed during the fermentation and reached their maxima from 24-30 hours after inoculation. By all ordinary conceptions such a medium should be free from sugar. No further adjustment of reaction was required since after heating to kill $\mathrm{B}$. welchii the medium had a $\mathrm{P}_{\mathrm{H}}$ value equal to 7 . The lot was divided into 2 portions, to one of which $1 \%$ glucose was added. These portions were tubed in the new constricted fermentation tubes. Sterilization performed was by the intermittent method. The mediums were inoculated from new brain cultures and incubated at 37 C. Daily readings were made for total gas production using Frost's gasometer and recorded in percentage of the total length of the closed arm occupied by the gas. No readings were made on the fifth day. 
On the sixth day tests for aerobic contamination were made from the open branch by spotting on plain agar and incubating aerobically. No aerobic contamination occurred. The tests for reaction change were made from the open branch also, for in all cases the broth in the

TABLE 3

Gas and Acid Production of Certain Anaerobes in Sugar-Free Broth and in GLUcose Broth

\begin{tabular}{|c|c|c|c|c|c|c|c|}
\hline \multirow{2}{*}{$\begin{array}{l}\text { Onlture } \\
\text { Number }\end{array}$} & \multirow{2}{*}{$\begin{array}{l}\text { Culture } \\
\text { Name }\end{array}$} & \multicolumn{3}{|c|}{ Sugar-Free Broth } & \multicolumn{3}{|c|}{ Sugar-Free Broth PIus $1 \%$ Glucose } \\
\hline & & $\begin{array}{c}\text { Total } \\
\text { Gas* }\end{array}$ & $\begin{array}{l}\text { Carbon } \\
\text { Dioxide }\end{array}$ & $\begin{array}{c}\text { Reaction } \\
\text { Change }\end{array}$ & $\begin{array}{c}\text { Total } \\
\text { Gas }\end{array}$ & $\begin{array}{l}\text { Carhon } \\
\text { Dioxide }\end{array}$ & $\begin{array}{c}\text { Reaction } \\
\text { Ghange }\end{array}$ \\
\hline Control & Uninoculated & Trace & .. & None & Trace & .. & None \\
\hline \multirow[t]{2}{*}{1} & B. tetani & $\begin{array}{l}10 \\
12 \\
12\end{array}$ & & & $\begin{array}{l}12 \\
12 \\
12\end{array}$ & & \\
\hline & & 13 & 10 & Alkaline & 13 & 10 & Alkaline \\
\hline \multirow[t]{2}{*}{2} & B. welchii & $\begin{array}{c}\text { Trace } \\
5 \\
5 \\
5\end{array}$ & & & $\begin{array}{l}21 \\
25 \\
30 \\
25\end{array}$ & & \\
\hline & & 5 & 0 & None & 22 & 18 & Acid \\
\hline \multirow[t]{2}{*}{4} & $\begin{array}{l}\text { Vibrion } \\
\text { septique }\end{array}$ & $\begin{array}{c}\text { Trace } \\
5 \\
5 \\
7\end{array}$ & & & $\begin{array}{l}15 \\
13 \\
30 \\
30\end{array}$ & & \\
\hline & & 6 & 0 & None & 25 & 20 & Acid \\
\hline \multirow[t]{2}{*}{$8 \mathrm{~A}$} & B. botulinus & $\begin{array}{l}\text { Trace } \\
\text { Trace } \\
\text { Trace } \\
\text { Trace }\end{array}$ & & & $\begin{array}{c}\text { Trace } \\
5 \\
12 \\
15\end{array}$ & & \\
\hline & & $\overline{\text { Trace }}$ & .. & Alkaline & 20 & 100 & Acid \\
\hline \multirow[t]{2}{*}{10} & B. sporogenes & $\begin{array}{l}\text { Trace } \\
\text { Trace } \\
\text { Trace } \\
\text { Trace }\end{array}$ & & & $\begin{array}{r}3 \\
12 \\
17 \\
25\end{array}$ & & \\
\hline & & Trace & .. & Alkaline & 30 & 100 & Acid \\
\hline \multirow[t]{2}{*}{50} & $\begin{array}{l}\text { B. bifer- } \\
\text { mentans }\end{array}$ & $\begin{array}{l}\text { Trace } \\
\text { Trace } \\
\text { Trace } \\
\text { Trace }\end{array}$ & & & $\begin{array}{c}\text { Trace } \\
20 \\
30 \\
35\end{array}$ & & \\
\hline & & Trace & $\because$ & Alkaline & 38 & 61 & Acid \\
\hline
\end{tabular}

* The numbers indicate daily readings in percentages of the length of the closed arm occupied by the gas. The pereentage of carbon dioxide and the reaction rbange wer determined on the sixth day.

open arm had become turbid by admixture from the anaerobic portion of the tube. Since it is known that both the titratable acidity and $\mathrm{H}^{+}$ ion concentration of the open arm and of the closed arm differ, and since that of the latter was inaccessible in this experiment without disturbing the gas, in which the principal interest in this experiment lay, 
only a qualitative determination of the change in reaction was made by comparison with the broth of the uninoculated control, in a porcelain test plate, using brom-thymol-blue $\left(\mathrm{P}_{\mathbf{H}}\right.$ range $\left.6.0-7.6\right)$ as the indicator.

Only the nonputrefactive anaerobes, $\mathrm{B}$. welchii, and Vibrion septique, and the faintly putrefactive B. tetani, produced appreciable gas in the sugar-free broth. That of $\mathrm{B}$. tetani was the same in quantity from sugar-free and glucose broth, as might be expected on the theory that this organism ferments no sugar. This is supported by the alkaline reaction of both lots of medium. Curiously there was an appreciable quantity of carbon dioxide in both, so for B. tetani it is impossible that carbon dioxide may be considered a criterion of fermentation. Both B. welchii and Vibrion septique produced more gas in glucose broth than in sugar-free broth and while the former contained carbon dioxide, the latter contained none. The terminal reaction of the sugar broth was acid while that of the sugar-free broth could not be distinguished from the uninoculated control. For these organisms both carbon dioxide and acid might be considered criteria of fermentation; total gas might be so considered only with reservations as to quantity.

The putrefactive anaerobes, B. botulism, B. sporogenes, and B. bifermentans produced no visible gas in the sugar-free broth, and the terminal reaction was strongly alkaline, much more so than the tetanus cultures. As observed in other experiments not here reported, these organisms, which are known to attack glucose, produced abundant gas from glucose broth, but the rate of production was considerably less rapid than that of the nonputrefactive anaerobes. And here, as elsewhere in our notes, we observe that the percentage of carbon dioxide tends to be considerably higher for the putrefactive anaerobes than for more versatilely fermentative nonputrefactive micro-organisms.

If we are to regard the gas produced by certain fermentative organisms in sugar-free broth as derived from proteins, we are in somewhat of a dilemma in finding that the most highly putrefactive anaerobes do not offer this difficulty in the interpretation of fermentation reactions. The only consistent phenomenon in the experiment is the reaction change which throughout permits the correlation of acidity with other evidence of fermentation.

An experiment was then planned to determine the effect of variation in the peptone buffer content of a medium. A lot of meat infusion was divided into 2 parts. To one was added $0.5 \% \mathrm{NaCl}$ and $0.5 \%$ Parke Davis and Co. peptone; to the other was added $0.5 \% \mathrm{NaCl}$ 
and 5\% Parke Davis and Co. peptone. Each was fermented out with $B$. welchii well past the turning point in the $\mathrm{PH}$ curve. The reactions were adusted to $\mathrm{PH} 7$ and from each, eight of the new constricted fermentation tubes were filled. The remainder of each lot of medium was again divided, $1 \%$ Pfanstiehl glucose C. P. being dissolved in one, $1 \%$ Baker's lactose C. P. to the other. These were likewise tubed and all were then sterilized by the intermittent method in the Arnold sterilizer.

These mediums were then inoculated from fresh brain cultures of three carefully purified and identified strains of anaerobes representing not only the extremes in fermentative action among bacteria but also wide differences in proteolytic action. Thus $B$. tetani ferments no carbohydrates, B. botulinus ferments glucose but not lactose, while B. welchii ferments both glucose and lactose. And in the ascending order of their proteolytic action they stand B. welchii, B. tetani, B. botulinus. It was thought that a comparison of the action of these organisms on mediums of similar protein but of differing carbohydrate content and on mediums of similar carbohydrate but differing protein content, with respect to total gas production, carbon dioxide ratio, titer, and direction of reaction change, should give the clue to the true criterion of fermentation. The results are shown in table 4 .

Each test was done in duplicate in order that one tube might serve for the determination of the carbon dioxide ratio, the other for the acidity tests. The tubes were incubated at $37 \mathrm{C}$, for 4 days during which daily observations of turbidity and total gas formation were made. Aerobic contamination tests made by subcultures on plain agar plates showed only a single contamination in one of the uninoculated controls.

The experiment was at once disappointing and instructive in failing to show, in the case of any of these organisms any notable gas production, during 4 days incubation at $37 \mathrm{C}$, in any single tube containing a sugar not definitely fermented.

B. tetani failed to grow in the tubes containing only $0.5 \%$ peptone and produced only traces of gas even in the $5 \%$ peptone mediums, although there was abundant evidence of growth in the turbidity of the cultures after the first day of incubation. B. tetani may be designated as an obligately putrefactive organism, although its putrefactive properties are feeble. B. botulinus which, with the exception of one tube of sugar-free medium, grew in both the $0.5 \%$ and the $5 \%$ peptone medium, likewise produced only a trace of gas in the latter in the 
TABLE 4

Relation of Buffer Content to Action of B. Tetani, B. botulinus, and B. Welchit on Glucose, Lactose, and Sugar-Free Broth

\begin{tabular}{|c|c|c|c|c|c|c|c|c|c|}
\hline & Peptone & Tube & & Tota & $1 \mathrm{Ga}$ & & $\% \mathrm{CO}$ & Titer* & $\begin{array}{l}\text { Reaction } \\
\text { Change }\end{array}$ \\
\hline $\begin{array}{l}\text { tetani } 1 \\
\text { Sugar-free........... } \\
1 \% \text { glueose........... } \\
1 \% \text { lactose........... }\end{array}$ & $\begin{array}{l}0.5 \% \\
5.0 \% \\
0.5 \% \\
5.0 \% \\
0.5 \% \\
5.0 \%\end{array}$ & $\begin{array}{l}\mathbf{a} \\
\mathbf{b} \\
\mathbf{a} \\
\mathbf{b} \\
\mathbf{a} \\
\mathbf{b} \\
\mathbf{a} \\
\mathbf{b} \\
\mathbf{a} \\
\mathbf{b} \\
\mathbf{a} \\
\mathbf{b}\end{array}$ & $\begin{array}{l}\overline{-} \\
t \\
t \\
\bar{t} \\
t \\
t \\
\frac{t}{t} \\
t\end{array}$ & $\begin{array}{l}\bar{Z} \\
\operatorname{tr} \\
\operatorname{tr} \\
\overline{-} \\
\overline{t r} \\
\frac{\operatorname{tr}}{Z} \\
\overline{\operatorname{tr}} \\
\operatorname{tr}\end{array}$ & $\begin{array}{l}\bar{Z} \\
\overline{\operatorname{tr}} \\
\operatorname{tr} \\
\overline{-} \\
\overline{t r} \\
\operatorname{tr} \\
\overline{t r} \\
\overline{t r}\end{array}$ & $\begin{array}{l}\bar{Z} \\
\operatorname{tr} \\
\operatorname{tr} \\
\overline{-} \\
\overline{t r} \\
\operatorname{tr} \\
\overline{-} \\
\overline{t r} \\
\text { tr }\end{array}$ & $\begin{array}{l}= \\
= \\
= \\
= \\
= \\
=\end{array}$ & $\begin{array}{l}-0.1 \\
-0.1 \\
-0.2 \\
-0.1 \\
+0.1 \\
+0.1 \\
+0.9 \\
+0.9 \\
0 \\
+0.1 \\
+0.4 \\
+0.4\end{array}$ & $\begin{array}{l}\text { None } \\
\text { None } \\
\text { slightly alkaline } \\
\text { Slightly alkaline } \\
\text { None } \\
\text { None } \\
\text { Slightly alkaline } \\
\text { Slightly alkaline } \\
\text { None } \\
\text { None } \\
\text { Slightly alkaline } \\
\text { Slightly alkaline }\end{array}$ \\
\hline $\begin{array}{r}\text { B. botulinus } 8 \mathrm{~A} \\
\text { Sugar-free.... } \\
1 \% \text { glucose... } \\
1 \% \text { lactose.... }\end{array}$ & $\begin{array}{l}0.5 \% \\
5.0 \% \\
0.5 \% \\
5.0 \% \\
0.5 \% \\
5.0 \%\end{array}$ & $\begin{array}{l}a \\
b \\
a \\
b \\
a \\
b \\
a \\
b \\
a \\
b \\
a \\
b\end{array}$ & $\begin{array}{r}- \\
t \\
t \\
t \\
5 \\
5 \\
t r \\
t \\
t \\
t \\
t\end{array}$ & $\begin{array}{r}t \\
\operatorname{tr} \\
\operatorname{tr} \\
40 \\
40 \\
30 \\
10 \\
t \\
t \\
\operatorname{tr} \\
\operatorname{tr}\end{array}$ & $\begin{array}{l}t \\
\operatorname{tr} \\
\text { tr } \\
45 \\
15 \\
50 \\
10 \\
t \\
t \\
\operatorname{tr} \\
\text { tr }\end{array}$ & $\begin{array}{r}\mathrm{t} \\
\mathrm{tr} \\
\mathrm{tr} \\
40 \\
16 \\
50 \\
12 \\
\mathrm{t} \\
\mathrm{t} \\
\mathrm{tr} \\
\mathrm{tr}\end{array}$ & $\begin{array}{l}= \\
\overline{-} \\
\frac{33}{75} \\
= \\
= \\
=\end{array}$ & $\begin{array}{l}-0.1 \\
-0.1 \\
+0.2 \\
+0.3 \\
= \\
= \\
+3.4 \\
+0.1 \\
+0.1 \\
+0.8 \\
+0.9\end{array}$ & $\begin{array}{l}\text { None } \\
\text { None } \\
\text { None } \\
\text { None } \\
\text { Acid } \\
\text { Acid } \\
\text { None } \\
\text { None } \\
\text { None } \\
\text { None }\end{array}$ \\
\hline $\begin{array}{l}\text { B. welchil } 2 \\
\text { Sugar-free.......... } \\
1 \% \text { glucose......... } \\
1 \% \text { lactose. ......... }\end{array}$ & $\begin{array}{l}0.5 \% \\
5.0 \% \\
0.5 \% \\
5.0 \% \\
0.5 \% \\
5.0 \%\end{array}$ & $\begin{array}{l}\mathbf{a} \\
\mathbf{b} \\
\mathbf{a} \\
\mathbf{b} \\
\mathbf{a} \\
\mathbf{b} \\
\mathbf{a} \\
\mathbf{b} \\
\mathbf{a} \\
\mathbf{b} \\
\mathbf{a} \\
\mathbf{b}\end{array}$ & $\begin{array}{l}\bar{Z} \\
\bar{z} \\
\overline{25} \\
12 \\
30 \\
35 \\
30 \\
30 \\
50 \\
60\end{array}$ & $\begin{array}{l}\bar{Z} \\
\bar{z} \\
\overline{20} \\
15 \\
30 \\
30 \\
25 \\
25 \\
50 \\
50\end{array}$ & $\begin{array}{l}\bar{Z} \\
\bar{Z} \\
\overline{20} \\
15 \\
30 \\
30 \\
25 \\
25 \\
50 \\
60\end{array}$ & $\begin{array}{l}= \\
\bar{Z} \\
\overline{20} \\
15 \\
30 \\
30 \\
25 \\
25 \\
40 \\
55\end{array}$ & $\begin{array}{l}\bar{z} \\
\bar{z} \\
\frac{\operatorname{tr}}{\overline{20}} \\
\frac{\overline{t r}}{20}\end{array}$ & $\begin{array}{l}-0.1 \\
-0.1 \\
+0.3 \\
+0.2 \\
+0.9 \\
+4.1 \\
= \\
+1.7 \\
+3.6 \\
-\end{array}$ & $\begin{array}{l}\text { None } \\
\text { None } \\
\text { None } \\
\text { None } \\
\text { Acid } \\
\text { Acid } \\
= \\
\text { Acid } \\
\text { Acid } \\
-\end{array}$ \\
\hline $\begin{array}{c}\text { Oontrol uninoculated } \\
\text { Sugar-free........... } \\
1 \% \text { glueose........... }\end{array}$ & $\begin{array}{l}0.5 \% \\
5.0 \% \\
0.5 \% \\
5.0 \% \\
0.5 \% \\
5.0 \%\end{array}$ & $\begin{array}{l}\mathbf{a} \\
\mathbf{b} \\
\mathbf{a} \\
\mathbf{b} \\
\mathbf{a} \\
\mathbf{b} \\
\mathbf{a} \\
\mathbf{b} \\
\mathbf{a} \\
\mathbf{b} \\
\mathbf{a} \\
\mathbf{b}\end{array}$ & $\begin{array}{l}= \\
= \\
= \\
= \\
= \\
=\end{array}$ & $\begin{array}{l}= \\
= \\
= \\
= \\
= \\
=\end{array}$ & $\begin{array}{l}\bar{z} \\
\bar{z} \\
\bar{z} \\
\bar{z} \\
=\end{array}$ & $\begin{array}{l}= \\
\bar{z} \\
= \\
\bar{z} \\
\bar{z} \\
\bar{z}\end{array}$ & $\begin{array}{l}\bar{z} \\
\bar{z} \\
\bar{z} \\
\bar{z} \\
\bar{z}\end{array}$ & $\begin{array}{c}-0.1 \\
-0.1 \\
+0.2 \\
+0.3 \\
+0.1 \\
+0.2 \\
+1.2 \\
\because \\
0 \\
+0.1 \\
0.5 \\
0.8\end{array}$ & $\begin{array}{l}\text { None } \\
\text { None } \\
\text { None } \\
\text { None } \\
\text { None } \\
\text { None } \\
\text { None } \\
\text { Contaminated } \\
\text { None } \\
\text { None } \\
\text { None } \\
\text { None }\end{array}$ \\
\hline
\end{tabular}

* Titer to brom-thymol-blue $\mathbf{P}_{\mathbf{H}}=7 ;-=$ no growth; $\mathrm{t}=$ turbidity indicating growth; gas production indicated by $\operatorname{tr}$ (trace) or numbers which refer to percentage of closed arm occupied in the case of total gas, and to percentage of total gas in case of carbon dioxide. Titration values indicate percentage normal acid $(+)$ or alkali $(-)$. 
sugar-free and lactose cultures. B. welchii failed to give any evidence of growth in sugar-free broth; it may be designated as an obligately fermentative micro-organism. The results, which would admit total gas as a criterion of fermentation, cannot be reconciled with those shown in table 3 although they appear to be remarkably consistent throughout each separate experiment.

Certain points in the observation of the fermented tubes are significant. Again we note the slower but ultimately greater gas production of the putrefactive $B$. botulinus as compared with the saccharolytic B. welchii, in their action on glucose, although in each set with B. botulinus there were discrepancies in the duplicates which cannot be accounted for. Also with both organisms the total gas production was greater with $5.0 \%$ peptone. These phenomena were almost certainly due to the buffer action of the peptone. The total gas production with B. botulinus was greater possibly because of the increase of buffer capacity through proteolysis.

The equipment was not sufficiently delicate to measure the carbon dioxide in those tubes showing only traces of total gas. In all tubes showing cosiderable total gas, the carbon dioxide ratio was, as always before, higher with the proteolytic organism in similar mediums and also distinctly higher with both the proteolytic B. botulinus and the saccharolytic $B$. welchii in the medium rich with peptone. While this might be thought to be due to the more vigorous growth, it is not easy to see why the ratio of carbon dioxide to other gases should be so affected. B. welchii produced only the barest trace of carbon dioxide in the lightly buffered medium either with glucose or lactose.

The reaction changes were determined by the test plate method already described, using culture fluid from the small branch after removing the rubber stopper. Only the titer to brom-thymol-blue was ascertained.

In sugar-free medium there was no significant change either in $\mathrm{H}^{+}$ ion concentration or in titer, as compared with the uninoculated controls, except in the case of $\mathrm{B}$. tetani in $5 \%$ peptone medium; this was slightly alkaline, both in its reaction change and in titer. A similar change occurred with $B$. tetani in the medium plus glucose and lactose respectively. It is apparent that the introduction of the sugars brought about an increase in titratable acidity in these mediums, but the direction of reaction change due to $B$. tetani was the same in all. 
We were unable, in this experiment, to note any distinct alkaline change in the sugar-free broth inoculated with $B$. botulinus, as in table 3, the lactose broth also had remained practically stationary in reaction.

Turning to those cultures in which considerable gas was formed, all had increased markedly in $\mathrm{H}^{+}$ion concentration and in titratable acidity. The latter was especially notable in the richly buffered medium, but the former was equally distinct in the $0.5 \%$ peptone broth as would be expected. It is apparent that a high titratable acidity is correlated with a high buffer content which may be conceived to operate by permitting the more complete hydrolysis of the sugars.

This experiment alone would admit the validity as criteria of fermentation of: (1) total gas formation amounting to over $10 \%$ of the closed branch within 48 hours, (2) a distinct increase in titratable acidity, and (3) a distinct increase in $\mathrm{H}$ - ion concentration. It would deny the validity of carbon dioxide as a criterion in view of its reduction to the vanishing point in a medium containing little protein which still supports active fermentation of suitable sugars by $B$. welchii. The absence of carbon dioxide from these tests in which fermentation is otherwise indicated and its presence in the tetanus cultures of table 3 in which there is no other evidence of fermentation eliminates it from further consideration in this paper.

We have remaining the criteria of total gas production, titratable acidity, and increased $\mathrm{H}^{+}$ion concentration.

The perfect correlation of vigorous gas production and acidity changes in table 4 as contrasted with table 3 might suggest that the supposedly sugar-free medium of table 3 was actually not sugar-free, judging from the growth of $B$. welchii and Vibrion septique in it. But the fact that B. tetani produces gas in any medium in which it grows can lead to only one of two conclusions, either gas is not a reliable criterion of fermentation or the tetanus bacillus is a fermentative organism, and the latter supposition is not supportable.

Thus, while gas production is a criterion of fermentation for certain anaerobic as well as aerobic micro-organisms, there are organisms such as B. tetani, for which it is not a criterion, and its utility is limited to those bacteria which do not produce it in supposedly sugar-free medium.

The experiments up to this point indicated the reliability of vigorous gas production as a suitable criterion of fermentation when the control tests without sugar show only slight or no gas production. One 
cannot always insist that such control tests should show evidence of growth in view of the failure of certain saccharolytic organisms to grow in the absence of fermentable carbohydrates; whether such gas as is produced should be attributed to proteolysis alone depends on the organism. B. tetani appears to produce gas by proteolysis; most other proteolytic organisms do not. The anaerobes which give the most difficulty in the interpretation of fermentation in tests in which gas is the criterion are to be found among the saccharolytic groups which are relatively less active protein splitters. The inevitable conclusion is that gas formation in the "sugar-free" control in such cases is due to sugar which was not fermented out of the medium. This is likely to be the case especially when Bact. coli or Bact. saccharolyte are used for this purpose. It is less likely to be true when B. welchii is used. ${ }^{13}$ Meat infusion peptone broth fermented out with $\mathrm{B}$. welchii gives little difficulty in utilizing vigorous gas production as a criterion of fermentation for even with $5 \%$ peptone abundant gas production does not occur except in the presence of fermentable sugars.

The conclusions as to the acceptability of gas as a criterion of fermentation relate purely to peptone medium prepared as described. The possibility that proteolytic organisms may produce gas from native protein, such as casein, serum or egg albumin in the absence of fermentable sugars remains for more detailed study. The point is important because most of the present accepted records ${ }^{24}$ of anaerobic fermentation reactions are based on the work of Henry, ${ }^{18}$ who used egg albumin as an indicator for acid production in a casein digest medium. As for the casein in milk, our results in table 1 show a small amount of gas production by certain putrefactive anaerobes, but this may have been derived from the fermentation of the small amount of monosaccharide which Smith ${ }^{25}$ and Jones ${ }^{26}$ have shown to exist in milk, or by the indirect hydrolysis of the lactose. We have no data on the possibility of gas production from sugar-free casein, but it is well known that blood serum contains sugar. ${ }^{2 \top}$ Hammersten (p. 601) also refers to the presence of a fermentable carbohydrate in egg albumin and points out that "the protein substances of the white of egg behave like glycoproteins, as they all yield glucosamine." The addition of these substances

\footnotetext{
24 Reports of the Committe upon Anaerobic Bacteria and Infections, Medical Research Committee-Special Report Series, No. 12,1917, and No. 39, 1919; also footnote 7.

25 Jour. Boston Soc. Med. Sc., 1897, 2, p. 236.

so Jour. Infect. Dis, 1914,15, p. 357 .

27 Hammersten: Textbook of Physiological Chemistry, 1912, p. 256.
} 
to sugar-free mediums for the purpose of enrichment or as indicators may confuse the readings in the controls through the addition of fermentable sugars.

There is a possiblity that this is true also of agar, which, consisting mainly of d-galactose, a carbohydrate belonging to the group of pentosans, is subject to hydrolysis by autoclaving. ${ }^{28}$ Fellers ${ }^{29}$ quoted Tollens and Bourgeois "Hydrates de carbone" as saying "lactose and mixtures of glucoses have been crystallized from agar treated with dilute acids," although Fellers was unable to repeat this and failed to demonstrate gas formation by Bact. coli and yeasts in fermentation tubes.

That serum, egg albumin and agar may be used in aerobic fermentation tests without causing discrepancies means nothing in the study of anaerobic micro-organisms whose metabolism is so much more vigorous.

ACID AS A CRITERION OF ANAEROBIC FERMENTATION

All gas-forming aerobes produce also some acid and many fermentative aerobes produce acid without gas; acid is even more widely used than gas as a single criterion of aerobic fermentation. For many years it was customary to utilize merely the qualitive fact of acid production; then it became the fashion to measure the titratable acidity, and now the $\mathrm{H}^{+}$ion concentration, usually expressed in terms of $\mathrm{P}_{\mathrm{H}}$ value, is most popular as a criterion of acidity. Each of these steps has marked a development in our conception of the fundamental chemistry of the fermentative reaction.

\section{TITRATABLE ACIDITY}

The invalidity of titratable acidity as a criterion of direct lactose fermentation in milk by anaerobes has been pointed out in connection with table 1 which shows that the nonfermenting B. botulinus, $B$. sporogenes, and $B$. bifermentans produced titration values similar to that of B. welchii which ferments lactose, whereas Vibrion septique and $\mathrm{B}$. chauveauii which also ferment lactose, judging by their reaction changes, produced lower titration values. Unquestionably the high titration of milk cultures of the putrefactive anaerobes are dependent in part on the increased buffer capacity of the hydrolyzed casein, although the indirect fermentation of the lactose may also be concerned,

23 Noyes: Science, 1916, 44, p. 797.

29 Soil Science, 1916, 2, p. 255; Jour. Ind. and Eng. Chem., 1916, 8, p. 1128. 
Cwing to certain technical difficulties that we hope to overcome, we have not yet been able to find out whether sugar-free casein shows a similar increase in buffer capacity on proteolysis by these organisms. Attention is directed to the influence of coagulable protein in the titration curve of $\mathrm{B}$. welchii. ${ }^{13}$

Peptone, even in $5 \%$ concentration, introduces no difficulty of interpretation for the organisms tested, as may be seen in table 4 . In fact, there was a decrease in titratable acidity with $B$. tetani in all the highly buffered mediums, and while there was no notable decrease in titer with $\mathrm{B}$. botulinus in lactose peptone broth, there was also no evidence of an indirect attack on lactose, such as may be observed in milk. On the contrary, there is in the data displayed in table 4, a perfect correlation of abundant gas formation, high titration, and increased $\mathrm{H}^{+}$ion concentration in the action of $\mathrm{B}$. botulinus on glucose, and of B. welchii on both glucose and lactose.

\section{HYDROGEN-ION CONCENTRATION}

All in all, reaction change in the direction of increased $\mathrm{H}^{+}$ion concentration seems to be the most constant criterion of fermentation. It has not seemed necessary to the writer in the present investigation to determine the actual $P_{\mathrm{H}}$ values, though none may dispute a degree of satisfaction that attends the contemplation of a numerical record. Yet a serious question may be raised as to the absolute value of such records before we have learned to use qualitative methods with assurance. It is more important for present purposes to record and interpret the direction of change in $\mathrm{H}^{+}$ion concentration than it is to record those quasi-absolute values represented in titration and $P_{\mathrm{II}}$ determinations in "standard" mediums incubated for a "standard" time at a "standard" temperature without any clear recognition of whether the sugar present is an excess or less than an excess, or what the relation of sugar to protein may be, or what the influence of time.

In addition to its uniformity as a criterion of fermentation, an increase in $\mathrm{H}^{+}$ion concentration has the added advantage over gas as a criterion, that, if brought about by the presence of a relatively small amount, i. e., less than an excess, of an unsuspected fermentable carbohydrate, the exhaustion of the sugar will effect a reversion. whereas gas is more persistent. There is therefore less tendency to confusion in the controls, and full reliance may be placed in a negative result showing alkalinity even with slight gas production. 
Among recent students of anaerobes both qualitative and quantitative tests for acidity have been employed. Distaso and Martinez ${ }^{30}$ in 1913 used a deep semisolid agar medium with litmus as the indicator. This dye is decolorized in the depths by the growth of anaerobes, but shows the direction of the reaction change at the surface in contact with air. Meyer ${ }^{14}$ Simonds ${ }^{5}$ and Esty ${ }^{5}$ have left records in terms of titratable acidity using phenolphthalein as the indicator. But the most recent trend appears to be toward the use of purely qualitative tests as in the work of Robertson, ${ }^{6,}{ }^{15}$ Henry ${ }^{18}$ and Adamson. ${ }^{31}$ Henry, ${ }^{18}$ whose insight into the problem has already been mentioned, pointed out that for some organisms, peptone solution lacks sufficient nutriment, and he employed a neutral pancreatic digest of casein with egg albumin as an indicator, whose coagulation shows the production of acid. In doubtful cases litmus might be added; its inclusion previous to incubation was found to be valueless because of its decolorization under the paraffin used as a seal.

At one time during the course of the present investigation and before the point of view expressed in the foregoing paragraphs was reached, the writer hoped to find an indicator that might be added to the mediums in order to enable the investigator to follow the $\mathrm{H}^{+}$ion changes in the closed branch of the tube without disturbing the culture. Such an indicator should have the following characteristics:

1. It should show distinct color changes throughout a relatively wide range of $P_{H}$ values on both the acid and the alkaline sides of the neutral point, i. e., $\mathrm{P}_{\mathrm{H}}=7.0$.

2. It should be neither decolorized nor destroyed by sterilization under anaerobic conditions.

3. It should be noninhibitive in the concentration required as an efficient indicator.

4. It should not be decolorized or destroyed by the growth of anaerobic organisms.

These requirements have not been found combined in a single indicator or combination of dyes. Table 5 presents the findings on a few whose known $\mathrm{H}^{+}$ion concentration ranges suggested their possible usefulness. A number of dyes, whose range lies wholly on one side of the neutral point, were tested with the possibility in view that they

so Compt, rend. Soc. de biol., 1913, 75, p. 201.

s1 Jour. Path, \& Bacteriol, 1919, 22, p. 345. 
might be combined with another having a complementary range on the other side of the neutral point. The ranges were determined in buffer solutions of known $\mathrm{P}_{\mathrm{H}}$ values.

The azolitmin was an old sample of Merck's. The phenol red, bromthymol-blue, cresol red, and brom-cresol purple, were made by Hynson, Westcott and Company. The source of the China blue used separately is unknown. The China blue-phenol red mixture was made up according to Morishima's formulä. ${ }^{32}$ The China-blue rosolic-red

TABLE 5

A Study of Certain Dyes with Refrrtince to Their Posstbile Utility as Direct Indicators of $\mathrm{H}^{+}$Ion Changes in Anaerobic: Cut.tures

\begin{tabular}{|c|c|c|c|c|c|c|c|c|}
\hline \multirow[b]{2}{*}{ Indicator } & \multirow[b]{2}{*}{$\begin{array}{c}\mathbf{P H}_{\mathrm{H}} \\
\text { Range }\end{array}$} & \multirow[b]{2}{*}{$\begin{array}{l}\text { Concentra- } \\
\text { tion }\end{array}$} & \multicolumn{3}{|c|}{$\begin{array}{l}\text { B. welehij } 2 \text { in } \\
\text { Glucose Broth }\end{array}$} & \multicolumn{3}{|c|}{$\begin{array}{l}\text { B. tetani } 1 \text { in } \\
\text { Sugar-free Broth }\end{array}$} \\
\hline & & & $\begin{array}{l}\text { Decol- } \\
\text { oriza- } \\
\text { tion } \\
\text { by } \\
\text { Heat }\end{array}$ & Growth & $\begin{array}{l}\text { Decol- } \\
\text { oriza- } \\
\text { tion } \\
\text { by } \\
\text { Growth }\end{array}$ & $\begin{array}{l}\text { Decol- } \\
\text { oriza- } \\
\text { tion } \\
\text { by } \\
\text { Heat }\end{array}$ & Growth & $\begin{array}{l}\text { Deeol- } \\
\text { oriza- } \\
\text { tion } \\
\text { by } \\
\text { Growth }\end{array}$ \\
\hline Azolitmin..... & $6.8-7.8$ & $1: 2.000$ & $+*$ & + & $-1 *$ & $+*$ & + & $+*$ \\
\hline Phenol red.... & $6.7-8.4$ & $1: 100,000$ & - & + & $\begin{array}{l}\text { Perma- } \\
\text { nent }\end{array}$ & - & $\cdot+$ & Partial \\
\hline China blue............ & $5.0-7.0$ & $1: 20,000$ & - & + & $\begin{array}{l}\text { I'erma- } \\
\text { nent }\end{array}$ & & & \\
\hline Phenol red, china blue & $5.0-8.4$ & $\begin{array}{l}\text { P.R. 1:1000000 } \\
\text { C.B. 1:10,000 }\end{array}$ & - & + & $\begin{array}{l}\text { Perma- } \\
\text { nent }\end{array}$ & & & \\
\hline China blue, rosolic acid & $\begin{array}{l}\text { Not } \\
\text { deter- }\end{array}$ & $\begin{array}{l}\text { O.B. } 1: 40,000 \\
\text { R.A. } 1: 20,000\end{array}$ & $\ldots$ & + & $\begin{array}{c}\text { Perma- } \\
\text { nent }\end{array}$ & & & \\
\hline Brom-thymol-blue.... . & $6.0-7.6$ & $1: 25,000$ & +1 & + & $\begin{array}{c}\text { Slow but } \\
\text { perma- } \\
\text { nent }\end{array}$ & $+\dagger$ & -- & \\
\hline Cresol red... & $7.2-8.8$ & $1: 50,000$ & $+t$ & + & $\begin{array}{c}\text { Negative, } \\
48 \text { hours }\end{array}$ & $+\dagger$ & + & $\begin{array}{l}\text { Negative, } \\
48 \text { hourg }\end{array}$ \\
\hline Hematin............. & $6.0-8.2$ & $1: 20,000$ & $-\ldots$ & - & & & & \\
\hline Acid fuchsin.......... & $6.4-8.2$ & $1: 20,000$ & - & + & $\begin{array}{l}\text { Slow but } \\
\text { perma- } \\
\text { nent }\end{array}$ & --- & + & $\begin{array}{l}\text { Slow but } \\
\text { perma- } \\
\text { nent }\end{array}$ \\
\hline Brom-cresol purple. & $5.2-6.8$ & $1: 50,000$ & - & + & $\begin{array}{c}\text { Perma- } \\
\text { nent }\end{array}$ & - & -- & \\
\hline Neutral red.......... & $7.6-8.6$ & $1: 10,00$ & - & + & $\begin{array}{l}\text { Perma- } \\
\text { nent }\end{array}$ & $\ldots$ & -- & \\
\hline
\end{tabular}

* Tenporary: Color regained aerobically on cooling, not anacrobically except on expogure to air

t Partial: Color regained aerobically and anaerobically on cooling.

mixture was kindly supplied by Dr. Bronfenbrenner ${ }^{33}$ and used according to the directions on the bottle. The hematein and neutral red were old samples of Grubler's. The acid fuchsin was Harmer's and was used in a concentration equivalent to that in Andrade's indicator.

The study of these dyes was begun by determining the limit of usefulness in graded dilutions of $\mathrm{N} / 20$ lactic acid and N/20 ammonia.

32 Jour. Infect. Dis., 1920, 26, p. 43.

33 Jour. Med. Research, 1918, 34, p. 25. 
which were selected because they are the chief agents that affect the reaction in bacterial cultures. After determining the limit of useful dilution of dye, the useful range of each was determined in a graded series of standard buffer solution. The first tests were made in constricted tubes with marble seals with glucose broth $\left(P_{\mathrm{H}}=7.4\right)$ containing these dyes in the indicated concentrations.

The tubes were examined for decolorization by heat after each intermittent sterilization. In such tests the constricted tube provides both aerobic and anaerobic conditions so that the return of color that occurs with some dyes when their leuko-bases are exposed to the air may be readily observed above the seal and contrasted with the failure of recolorization below the seal.

Only axolitmin failed to meet the requirement of not decolorizing during sterilization for while brom-thymol-blue and cresol-red were partially decolorized by heating, they completely regained their color both aerobically and anaerobically on cooling.

B. welchii was selected for its active fermentative properties as the test organism in glucose broth. Of the dyes tested in glucose broth, only hematin proved inhibitive. In all the rest growth was shown by turbidity and abundant gas formation at $37 \mathrm{C}$, in less than 24 hours.

Cresol red was the only dye not decolorized by growth of $\mathrm{B}$. welchii in glucose broth; it is of no value as an indicator of acid, however, on account of its range which lies on the alkalin side, but it might prove to be a satisfactory component of a combination with some other dye.

Both brom-thymol-blue and acid fuchshn have a correct range, but they were destroyed by the growth of the organism. Neither exposure to air nor the addition of either acids or bases caused either of them to regain their indicator properties after 48 hours' incubation. These two dyes were less rapidly destroyed however than phenol red, China blue, China-blue-rosolic acid, phenol red China blue, brom-cresol-purple and neutral red, all of which were completely and permanently decolorized at 24 hours.

Azolitmin alone of all the dyes sensitive to both acids and alkalines at the neutral point was not destroyed by the growth of $\mathrm{B}$. welchii in glucose broth, although it is of no value for the direct determination of $\mathrm{H}^{+}$ion concentration owing to its decolorization under anaeorbic conditions both by heat and by growth. Such decolorized azolitmin retains its indicator properties when exposed to air, however. Moreover, 
the medium above the seal was not decolorized and served in situ as a valuable qualitative indicator of increased $\mathrm{H}^{+}$ion concentration.

The question was raised as to whether decolorization of these dyes might not in itself be regarded as a criterion of fermentation. This point was put to test using $B$. tetani, a nonfermentative organism, in sugar-free meat infusion broth fermented out with $B$. welchii. ${ }^{13}$ Although performed at a later time, the results of this experiment also are presented in table 5. So far as they go, they show that decolorization is not correlated with fermentation.

It was impossible to secure satisfactory growth of $B$. tetani in sugar-free broth with brom-thymol-blue, brom-cresol-purple or neutral red, although the tubes were reinoculated after 48 hours' incubation and reincubated. Otherwise the results were comparable with those with B. welchii in glucose broth.

Azolitmin behaved exactly as in glucose broth with $B$. welchii; it was decolorized below the marble seal and not above. When tested after 48 hours' incubation the decolorized dye regained its color (blue) on exposure to air in a test plate and was still sensitive to the addition of lactic acid.

Acid fuchsin at 48 hours was completely and permanently decolorized; it failed to react to the addition of lactic acid.

Phenol red at 48 hours was yellow in the culture tube, although a test of the solution with brom-thymol-blue showed distinct alkalinity. The phenol red was only partially decolorized, however, as it still reacted to strong lactic acid.

Cresol red appeared not to be destroyed in 48 hours, but its indicator properties in the tube were not altogether satisfactory.

It is curious that while the direct and progressive determination of $\mathrm{H}^{+}$ion concentration changes wrought by certain facultatively anaerobic bacteria may be made as noted by Bronfenbrenner, ${ }^{33}$ Morishima, ${ }^{32}$ Conn and Hucker ${ }^{34}$ and Medalia, ${ }^{35}$ it seems impossible to utilize these dyes similarly in the study of obligate anaerobes such as B. welchii and B. tetani. The outcome of our admittedly fragmentary search for an indicator for the direct determination of $\mathrm{H}^{+}$ion concentration has thus been disappointing. Only a qualitative determination of the direction of $\mathrm{H}^{+}$ion concentration change may be made using the dye in the medium, and for this litmus has proved so far the best indicator.

3* Jour. Bacteriol., 1920, 5, p. 433.

35 Ibid., 1920, 5, p. 441. 
Litmus must be used in such a way as to expose it both to the action of the air to avoid decolorization and to the influence of the acid formed by the anaerobes. This may be done in deep agar according to the method of Distaso and Martinez ${ }^{30}$ or in the constricted tube with marble seal. The writer has used both methods successfully in qualitative tests but prefers the latter in spite of its demand for a rather larger quantity of medium.

For quantitative tests it is still necessary to remove the culture fluid from the container. Our present methods leave much to be desired in this direction; the elaborate devices invented with this end in view by Wolf and Harris ${ }^{23}$ have already been mentioned. For purposes of following simply the titratable acidity and $\mathrm{H}^{+}$ion curves the method used by Randall and Hall ${ }^{13}$ is quite satisfactory.

\section{THE PRESENT STATUS OF THE. PROBLEMS OF ANAEROBIC FERMENTATION TESTS}

The experiments here outlined suggest the following observations:

The vigorous production of gas by anaerobes is generally to be regarded as an indication of fermentation. However, two sets of facts may confuse the utilization of gas as a criterion of fermentation in special cases; first, the production of gas from simple sugars present in the medium and not removed by the method of sugar removal generally employed, i. e., by fermentation with Bact. coli, and second, the production of small quantities of gas from proteins by certain organisms, such as B. tetani, not known to have any action on sugars. The first of these difficulties may be overcome through the use of $B$. welchii instead of Bact. coli in the preparation of sugar-free mediums.

The production of carbon dioxide by $B$. tetani in both sugar and sugar-free mediums also makes the utilization of carbon dioxide as a criterion of fermentation untenable.

The utility of titratable acidity as a criterion of fermentation is limited to mediums not containing coagulable proteins, the hydrolysis of which by proteolytic organisms greatly increases the buffer capacity of the titrated samples.

An increase in $\mathrm{H}^{+}$ion concentration is regarded as the best evidence of fermentation. It has the advantage over gas of nonpersistence when the protein phase of metabolism becomes dominant through exhaustion of small amounts of sugars not supposed to be included in a given test. 
No means of direct quantitative determination of $\mathrm{H}^{+}$ion concentration have been found. Certain dyes that have been so utilized in the study of aerobes are not only decolorized but destroyed by certain, possibly all, anaerobes. Litmus alone was found useful for qualitative tests. Its utilization in the constricted tube (with or without the gas collection tube) is suggested. Emphasis is laid on the comparison of all fermentation tests with uninoculated mediums and with inoculated sugar-free mediums. 